\title{
Spatial Integration of Non-Motorized Transport and Urban Public Transport Infrastructure: A Case of Johannesburg
}

\author{
Brightnes Risimati ${ }^{1, *}$, Trynos Gumbo $^{1}{ }^{10}$ and James Chakwizira ${ }^{2}$ \\ 1 Sustainable and Smart Cities and Regions Group, Department of Urban and Regional Planning, \\ University of Johannesburg, Johannesburg 0184, South Africa; tgumbo@uj.ac.za \\ 2 Urban and Regional Plannibg, North-West University, Potchestroom 2531, South Africa; 26878208@nwu.ac.za \\ * Correspondence: brightnesrisimati@gmail.com; Tel.: +27-78-3326-246
}

check for updates

Citation: Risimati, B.; Gumbo, T.; Chakwizira, J. Spatial Integration of Non-Motorized Transport and Urban Public Transport Infrastructure: A Case of Johannesburg. Sustainability 2021, 13, 11461. https://doi.org/ $10.3390 /$ su132011461

Academic Editor: Wann-Ming Wey

Received: 18 May 2021

Accepted: 21 June 2021

Published: 17 October 2021

Publisher's Note: MDPI stays neutral with regard to jurisdictional claims in published maps and institutional affiliations.

Copyright: (c) 2021 by the authors. Licensee MDPI, Basel, Switzerland. This article is an open access article distributed under the terms and conditions of the Creative Commons Attribution (CC BY) license (https:// creativecommons.org/licenses/by/ $4.0 /)$.

\begin{abstract}
Sustainability of transport infrastructure integration begins with involving an all-inclusive transportation chain instead of only focusing on one part of the journey. This is achieved by facilitating spatial integration between diverse transport modalities to allow for a multiplicity of travel opportunities. This paper unpacks the extent of the spatial integration of non-motorized transport and urban public transport infrastructure within the city of Johannesburg in South Africa. Cycling activity datasets derived from Strava Metro and the spatial data of urban public transport infrastructures were collected to demonstrate existing spatial patterns and infrastructure connectivity. Exploratory spatial data analysis and focal statistics analysis were central in the data processing. The findings reveal that cycling activities are separated from urban public transport infrastructure, and the city of Johannesburg's transport system is characterized by spatially fragmented commuting and cycling operations, with limited to no sharing of infrastructure. Most public transport stations are not easily accessible for non-motorized transport and are characterized by inadequate cycling facilities. In conclusion, the identification of an urban public transportation catchment area becomes essential for developing cities such as Johannesburg. This can be used as tool for planning infrastructural upgrades and forecasting potential public transport ridership while also assessing the impacts of investments in transit planning. There is thus a need to integrate motorized urban public transport and cycling infrastructural developments toward promoting multi-mobility and infrastructure sharing.
\end{abstract}

Keywords: cycling; urban public transport; infrastructure; integration; city of Johannesburg

\section{Introduction}

Contemporary transportation infrastructure is perceived as vibrant, with a long-lasting impetus on the morphology and dynamics of urban expansion and on sustainable and resilient urbanization [1]. There has been growth in the literature designed to unpack efforts to integrate and improve commuting and cycling infrastructures, seen as desirable for enhancing the possibility of multi-mobility [2-9]. Moreover, there has been growth in contemporary transportation research promoting transit ridership [10-13]. This lessens the negative impacts of automobile dependence, improves the quality of life and enhances social inclusion $[4,7,14]$. It provides a more environmentally friendly and healthier activity pattern [15]. Such urban mobility infrastructure planning helps achieve the principle of spatial integration, efficiency, accessibility, livability, safety, reliability, viability and environmentally friendly and cost-effective transportation systems $[1,16,17]$. These principles are used as gauges to monitor the sustainability, functionality and smartness of public transportation infrastructures $[15,18]$.

Over the last few decades, urban areas in both developed and developing cities have become increasingly automobile-dominated and less sustainable $[19,20]$. In developed countries, mainly cities such as Amsterdam in the Netherlands; London in the United Kingdom and Berlin in Germany, have witnessed a trend of reclaiming urban space from the automobile. Today, these cities are considered as principal examples of sustainable 
urban development. Similarly, transportation planning in developing countries such as South Africa has realized massive transport infrastructure investments, particularly in metropolitan areas. This has been designed to meet urban sustainability standards by improving public transport, encouraging non-motorized modes and limiting the use of private cars [15,21-23]. However, these infrastructure investments have been criticized in terms of spatial integration and efficiency [24,25]. Ranchordás [20] further articulated the critical need for the operation of well-integrated, efficient and affordable modern public transport systems in developing countries to ensure mobility within smart cities. The city of Johannesburg has recently contributed toward the improvement of integrated public transport infrastructure $[26,27]$. Such developments have included a comprehensive transportation chain. This was achieved through facilitating spatial integration between diverse transport modalities (for instance, cycling and commuting) to allow for a multiplicity of travel opportunities [28]. This research assesses the extent of spatial integration between cycling activities and urban public transportation infrastructure. The proposed analysis is illustrated in a developing city context, where cycling activities are impaired by accessibility constraints. This study contributes to the literature on the physical and spatial integration of cycling and motorized public transportation modalities [18,21].

\section{Study Area}

The city of Johannesburg is positioned centrally within the Gauteng Province in the Republic of South Africa. It is optimally located to access its surrounding metropolitan and local authorities (i.e., Tshwane to the north, Ekurhuleni to the east, Sedibeng District to the south and the West Rand District to the west). Moreover, it is well located to access neighboring provinces such as the Northwest, Limpopo, Mpumalanga and the Free State. The city is divided into 7 regions: Region A (Midrand, Fourways, Diepsloot, Lanseria and Ivory Park); Region B (Rosebank, Parktown, Hyde Park, Parkhurst, Kya Sands and Randburg); Region C (Roodepoort, Northgate, Florida, Zandspruit and Braam Fischerville); Region D (Soweto, Protea Glen, Naturena and Noordgesig); Region E (Sandton, Melrose, Alexandra, Houghton and Orange Grove); Region F (Inner City, Hillbrow, Turffontein, Doornfontein, Braamfontein, Glenvista and Kibler Park); and Region G (Orange Farm, Lenasia and Vlakfontein). Figure 1 provides a spatial perspective of the city of Johannesburg's regions.

The city has an extensive public transport network which includes primary bus and rail routes. For example, the Bus Rapid Transport Network (Rea Vaya) connects the CBD to major regional, district and local nodes and between the historic township localities, such as Soweto and Alexandra, and the primary economic nodes of the city [22,26]. Rea Vaya is supported by a vast railway network and the Gautrain system, which connects the city's outermost regions to the metro as well as the broader Gauteng region. The city of Johannesburg has invested in cycling infrastructure through policies such as the Non-Motorized Transport Framework (2009), the Johannesburg Integrated Transport Plan and the 2040 Growth and Development Strategy. The first of these cycling routes began with the Orlando Pilot project. This is one of three projects in South Africa for developing a non-motorized transportation network under the national Green Programme partnership between South Africa and Germany. The project consists of a 5-km route in Orlando, Soweto and a 4-km lane in the Inner City between the University of Johannesburg and the University of Witwatersrand $[27,29]$. Other cycling plans include a 3.5-km dedicated lane between Alexandra and Sandton and a 20-km lane linking the business districts of Rosebank, Melrose Arch and Sandton. These cycling interventions occurred together with substantial investment in the Rea Vaya BRT as well as the Gautrain. 


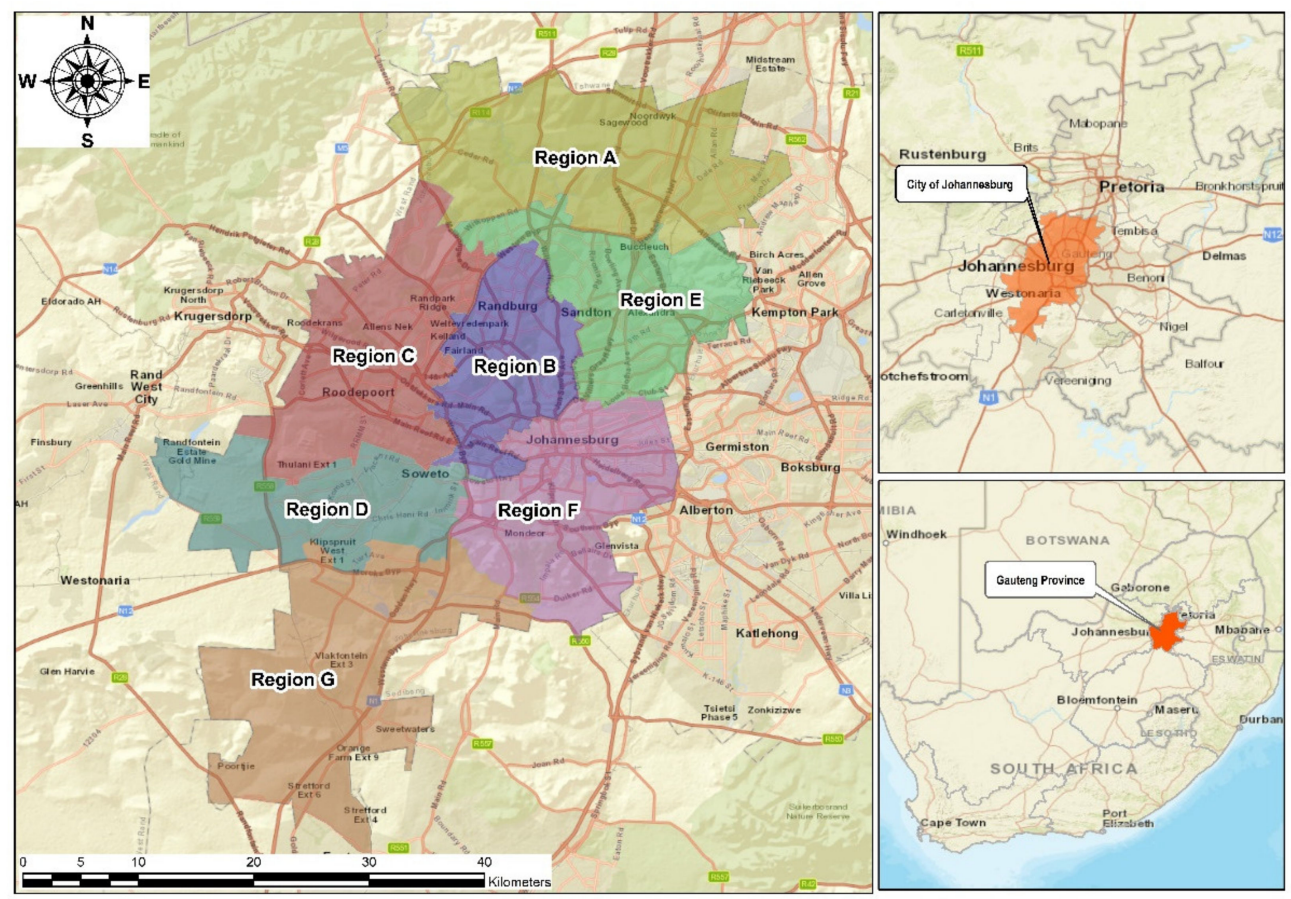

Figure 1. Map of the city of Johannesburg.

\section{Materials and Methods}

A mixed method approach utilized the spatial and qualitative methods of data collection and analysis to assess the spatial distribution patterns within the city of Johannesburg. The empirical enquiry consisted of a case study research design.

\subsection{Interviews}

The interviews were held with officials from the City of Johannesburg Metropolitan Municipality, the Johannesburg Roads Agency (JRA), the Johannesburg Development Agency (JDA), the Gauteng Department of Roads and Transport (Gautrans), the Passenger Rail Agency of South Africa (PRASA), the Johannesburg Metropolitan Bus Service (JMBS) and the Gautrain Management Agency (GMA). The interviews were used to unpack the policies that guide transport infrastructure development targets in line with the realities, needs and expectations of its current and potential users within the city of Johannesburg. Interviews were recorded on a smartphone with the permission of the interviewees. Following the completion of each day's interviews, the researchers transcribed the tapes within $72 \mathrm{~h}$ after each interview. The transcription process helped the researchers to unpack the responses of the interviewees. Table 1 lists the interview questions. 
Table 1. Interview questionnaire.

- What are the spatial plans and envisioned mobility innovations for the city of Johannesburg?

- In your professional opinion, are the policy and legislative instruments in place effective enough to facilitate the provision and management of well-integrated, affordable and reliable modern public transportation systems in South African cities?

- Do urban public transport services contribute to integration of residential and economic opportunities in Johannesburg?

- What is your professional opinion on the local economic transformation and improved accessibility to economic opportunities for formerly marginalized places of Johannesburg?

- What is the extent of spatial integration of transport infrastructure in the City of Johannesburg?

- Does the state of transport infrastructure integration have an impact on the level of public transport ridership and preference?

- How is the state's Non-Motorized Transport infrastructure in terms quality pedestrian and cycling routes?

- $\quad$ Does the NMT infrastructure extend across the city, connecting work, school and home destinations?

- In your professional opinion, is there any possibility of developing a comprehensive public transport framework that can be used to integrate the existing urban public transport systems?

- In general, are there any possible improvements you would like to see in terms of transport infrastructure in Johannesburg?

\subsection{Strava Metro Data}

Crowd-sourced datasets derived from the geolocation-based mobile application Strava Metro were collected for the city of Johannesburg to visualize cycling patterns and trend distributions. There are limited studies which have completed spatial datasets of nonmotorized spatial patterns in developing cities such as Johannesburg. Strava Metro data were therefore collected and analyzed, as they have been used in previous studies to conceptualize cycling patterns and trends [30-32]. Strava Metro utilizes data from Strava, a GPS-enabled smartphone application which can track bicycle rides and upload the data to an online community of other users. The GPS in a mobile device stores points as spatial data on Strava Metro [33,34], and Strava Metro packages this data in Excel format to enable cities to better understand cycling patterns.

The information was packaged in three categories, namely (1) streets, (2) nodes and (3) origins and destinations [30]. For this study's purpose, we acquired the origination and destination dataset which recorded cycling polygon activities' start and end points [35]. Data received from Strava were in dBASE and in shapefile format. The dBASE file contained all the cycling attributes, while the shapefile contained the location (suburbs) of the cycling activities in Johannesburg. The total number of cycling trips recorded by Strava Metro in Johannesburg was 101,141 for 2019 (from 1 January 2019 to 1 December 2019). During data capturing, the Strava Metro user must specify whether the activity is walking or cycling. Additionally, Strava Metro utilizes the average travel speed of the user to determine whether the user is walking or cycling. In Johannesburg, the average travel speed for cycling is $15 \mathrm{~km} / \mathrm{h}[21,36]$. Only about $17 \%$ of the cycling trips recorded were for commuting, while recreational trips accounted for approximately $83 \%$ of trips. Table 2 below illustrates the total cycling activities for the year 2019 in the city of Johannesburg.

Table 2. Summary of total cycling activities recorded by Strava Metro.

\begin{tabular}{ccc}
\hline Activity & Trips & Percentage \\
\hline Commuting & 16,844 & $17 \%$ \\
Recreational & 84,297 & $83 \%$ \\
Total & 101,141 & $100 \%$ \\
\hline
\end{tabular}




\subsection{Urban Public Transport Infrastructural Data}

The researchers collected spatial data of urban public transport infrastructures (Gautrain, Rea Vaya, Metrorail and Metrobus) in shapefile format from their service providers (Gautrain Management Agency, Passenger Rail Agency of South Africa (PRASA), Johannesburg Metropolitan Bus Service (JMBS) and the city of Johannesburg). The data gathered were used to visualize the spatial trend maps using a geographic information application (ArcGIS 10.3 software) to inform the analysis and discussion on spatial patterns and infrastructure connectivity of the urban public transport systems. Table 3 below summarizes the spatial datasets gathered, while Table 4 illustrates the spatial dataset's geolocation.

Table 3. Summary of spatial datasets collected.

\begin{tabular}{ccc}
\hline Datasets & Quantity \\
\hline Gautrain stations & & 5 train stations \\
Gaubus stations & Phase 1A & 31 bus stations \\
& Phase 1B & 46 bus stations \\
Rea Vaya stations & Phase 1C & 13 bus stations \\
& & 42 train stations \\
Metrorail stations & & 1921 bus stations \\
Metrobus stations & & \\
\hline
\end{tabular}

Table 4. Geolocation of spatial datasets collected.

\begin{tabular}{|c|c|c|c|}
\hline Column ID & Column Name & Unit & Interpretation \\
\hline 1 & Latitude & Degree & $\begin{array}{l}\text { Latitude reference of } \\
\text { infrastructural data }\end{array}$ \\
\hline 2 & Longitude & Degree & $\begin{array}{l}\text { Longitude reference of } \\
\text { infrastructural data }\end{array}$ \\
\hline 3 & Format & Point/Polyline & $\begin{array}{l}\text { Transportation routes or stations } \\
\text { R1 = Rea Vaya; M1 = Metrorail; }\end{array}$ \\
\hline 4 & Source & $\mathrm{R} 1 / \mathrm{M} 1 / \mathrm{M} 2 / \mathrm{G} 1 / \mathrm{G} 2$ & $\begin{array}{c}\text { M2 = Metrobus; G1 = Gautrain; } \\
\text { G2 = Gaubus }\end{array}$ \\
\hline 5 & Location & Point & Suburb or township \\
\hline 6 & Date & YYYYMMDD & $\begin{array}{l}\text { The day of the month or year } \\
\text { which infrastructural data was } \\
\text { last updated }\end{array}$ \\
\hline 7 & Time & HMS & $\begin{array}{l}\text { The time which infrastructural } \\
\text { data was last updated }\end{array}$ \\
\hline
\end{tabular}

The spatial coverage of the public transportation infrastructure was analyzed through exploratory spatial data analysis at the city and neighborhood level. The researcher used the focal statistics spatial analyst tool in ArcGIS 10.3. The focal statistics tool performs a neighborhood operation that computes an output raster, where the value for each output cell is a function of all the input cells in a specified neighborhood around that location. The function performed on the input is a statistic, such as the maximum, average or sum of all values encountered in that neighborhood. For this study, the sum of all values was used.

The researcher used a polygon E, representing the Johannesburg municipality regional boundary, as the processing extent. The set of public transportation station points was denoted as $S$, with each point $\mathrm{s} \in \mathrm{S}$ representing the public transportation mode stations. The set of event points $\mathrm{T}$ denoted the geographic location of each station point, with each point $\mathrm{t} \in \mathrm{T}$ having a numerical value $\mathrm{v}(\mathrm{t})$. Each public transportation network was denoted as $G=\{V, A\}$, where $V$ is a set of stations and $\mathrm{A}$ is a set of public transportation routes. Each route $a \in A$ is a path between two stations, and $v_{1} v_{2} \in V$ has a length $l(a)$. Lastly, $e(a, b)$ represents the straight line distance between station a and station $\mathrm{b}$. To conduct the focal statistics analysis, the following steps were used. 
Step 1: Create a fishnet with a grid size of $500 \mathrm{~m} \times 500 \mathrm{~m}$ within the spatial extent of polygon E. The length of $500 \mathrm{~m}$ was chosen as a suitable walking distance to a station as it was used in previous studies [29,36]. Step 2: Calculate the frequency of stations in each fishnet grid. Step 3: Calculate the focal sum as $\Sigma_{t \in N(s)}^{v(t)}$.

\section{Results}

The highest number of cycling trips occurred in the summer months of the year (9880), with September (7786), October (8928), November $(10,997)$ and December (6578) following them. In the middle of winter (June and July months), the patterns were common for both recreational and commuting cycling patterns. During the day, the cycling trips followed a discernible pattern, where most activities peaked in the morning hours between 6:00 a.m. and 9:00 a.m. and again between 3:00 p.m. and 5:00 p.m. for both recreation and commuting. The drawback of conventional and traditional methods of data collection techniques for cycling patterns such as traffic counts is that they cover a limited spatial extent and are often cumbersome to conduct. With Strava Metro data, this was circumvented, as they covered a broad spatial extent (national, provincial and local) and were regularly updated. Figure 2 illustrates the spatial coverage of cycling activities within the city of Johannesburg in 2019.

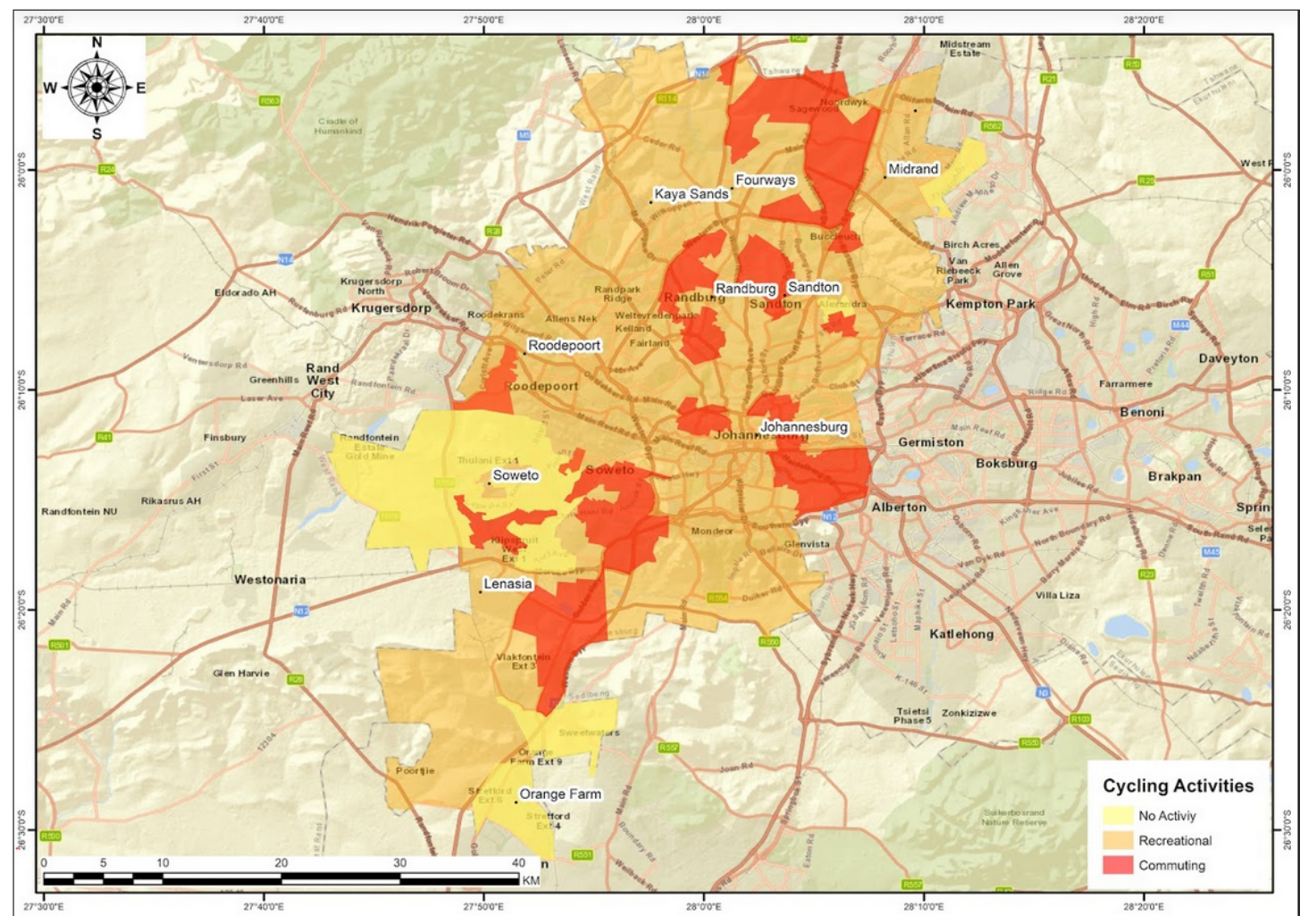

Figure 2. City of Johannesburg's spatial coverage of cycling activities in the year 2019.

It was observed that the most frequent cycling activities in the city were recreational, being observed at Kya Sands, Fourways, some parts of Midrand, Roodepoort and Lenasia. Commuting activities were observed in Sandton, Randburg, some parts of Midrand such as Sagewood and Noordwyk, some parts of the Inner City, Park Town, Hyde Park, Sandton, some parts of Soweto and Vlakfontein. Orange Farm and some parts of Soweto located in the south were cold spots with limited cycling activities. Figure 3 below illustrates the spatial coverage of urban public transport systems and the concentration of cycling activities. 


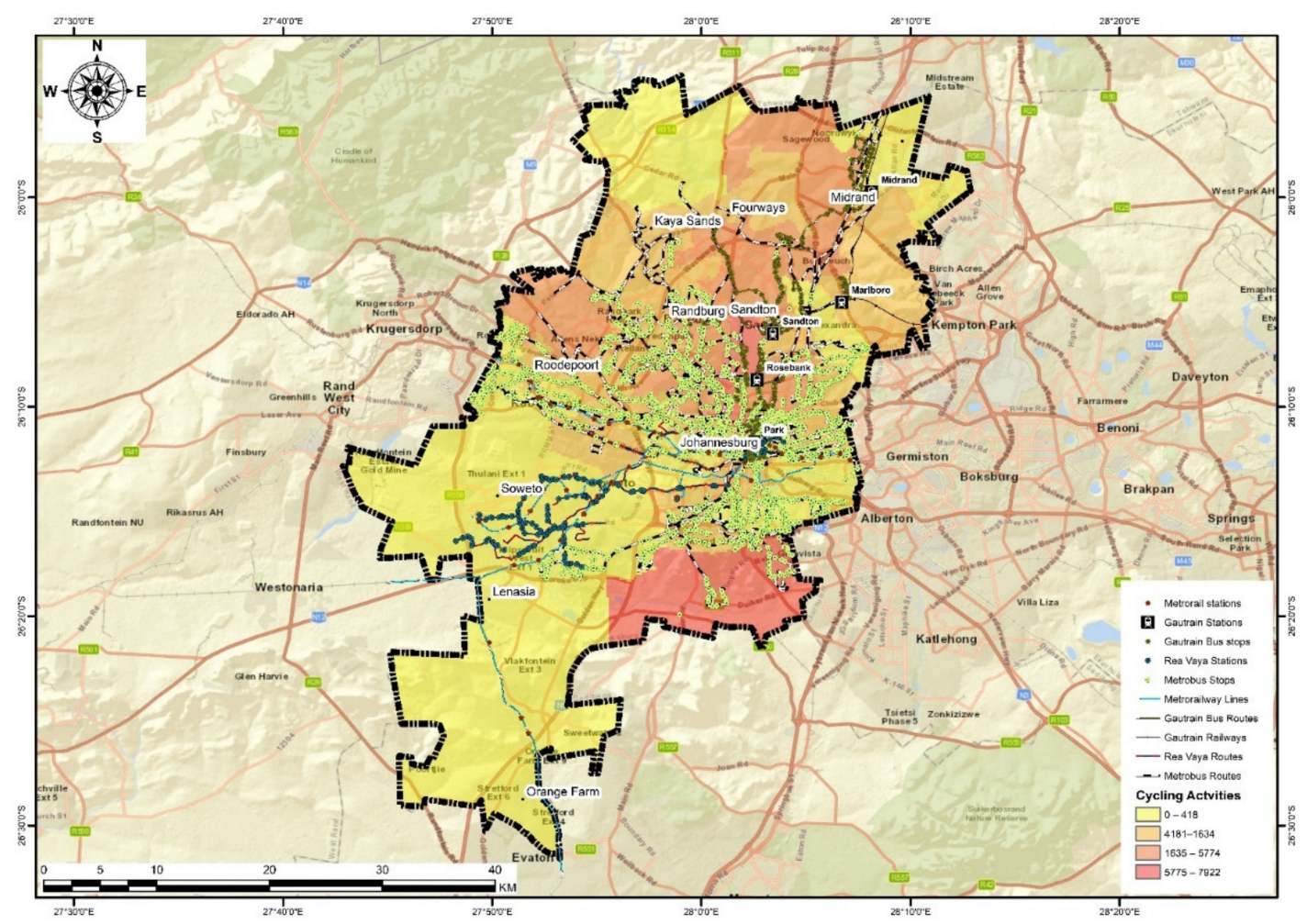

Figure 3. City of Johannesburg's spatial coverage of urban public transport modes and concentration of cycling activities.

The study revealed that most commuting and cycling operations were spatially fragmented, with limited to no sharing of their infrastructure in Johannesburg. The Gautrain, Rea Vaya, Metrorail and Metrobus in Johannesburg were also spatially separated from cycling activities. In most public transit stations, there are no adequate cycling infrastructures, and these stations are not easily accessible for non-motorized transport. In terms of hot spots for cycling, Parkview, Hyde Park, Sandton and Randburg comprised the highest number of cycling activities, with between 5775 and 7922 cycling trips recorded in 2019. This pattern was also most frequent for recreational and commuting cycling. For areas such as Roodepoort, Kya Sands, Fourways and Midrand, cycling activities ranged between 1635 and 5774. The cycling cold spots were mostly within the Inner City, Soweto, Lenasia and Orange Farm. Kibler Park south of Johannesburg in Region F and Sagewood in Midrand (Region A) did not have an urban public transport infrastructure providing commuting services, but they were hot spots for activity, with between 1635 and 5774 cycling trips recorded. This study reveals possible points of spatial integration of urban public transport modes and cycling activities, namely the Inner City, Rosebank, Soweto and Sandton City, as illustrated in Figures 4-7.

\subsection{Analysis of Johannesburg's Inner City Point of Integration}

Johannesburg's Inner City point of integration is comprised of Parktown, Park Station, New Town, Hillbrow, Marshalltown, Doornfontein and Braamfontein. This point of integration has the potential to connect public transportation for educational and health institutes such as the University of Johannesburg, University of Witwatersrand, Parktown Hospitals and several tertiary colleges in Braamfontein. The Gautrain bus routes, Metrobus as well as the Rea Vaya routes should also be noted as essential feeders in this area (refer to Figure 4). 


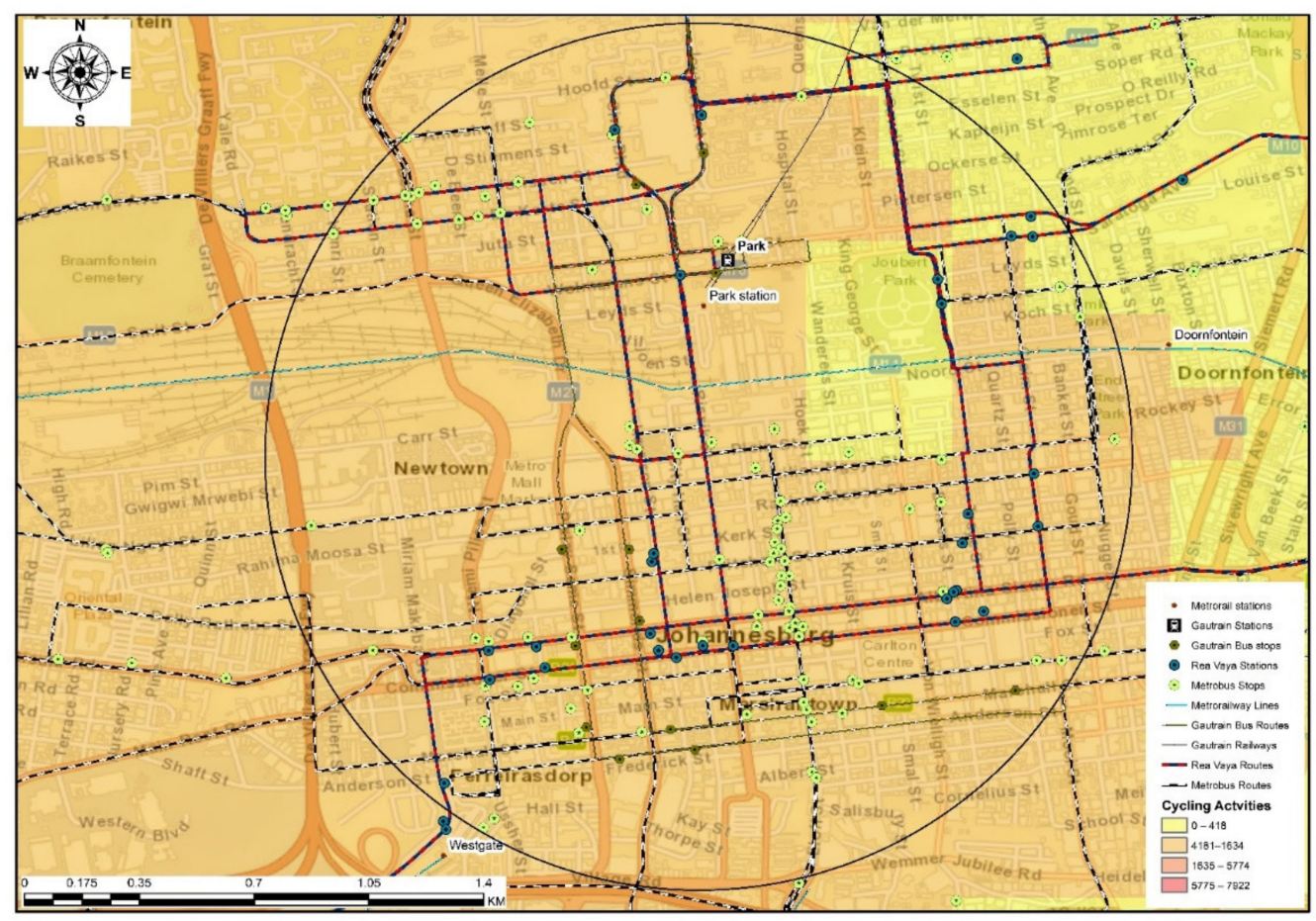

Figure 4. Inner City point of integration of urban public transport modes and concentration of cycling activities.

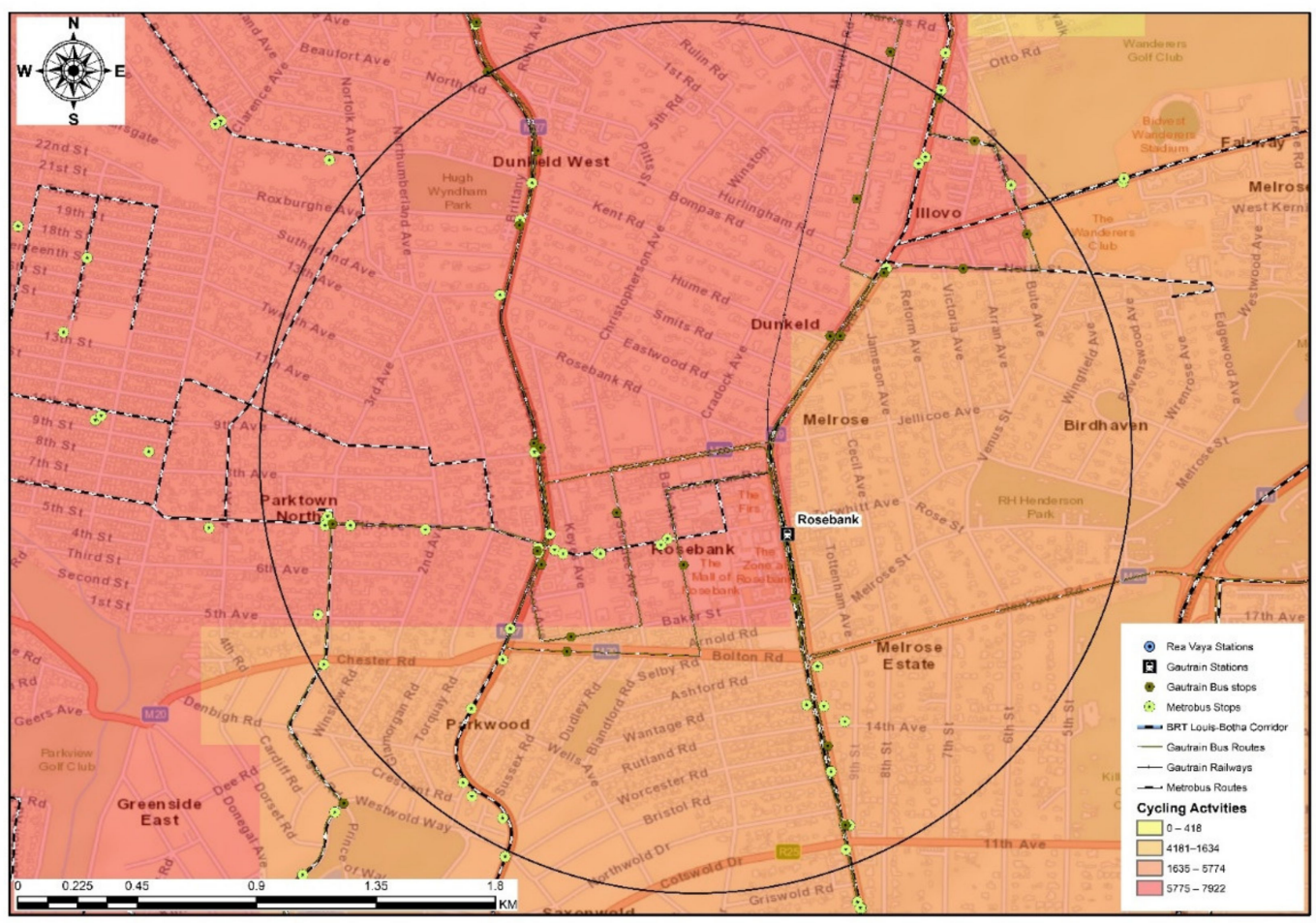

Figure 5. Rosebank point of integration of urban public transport modes and concentration of cycling activities. 


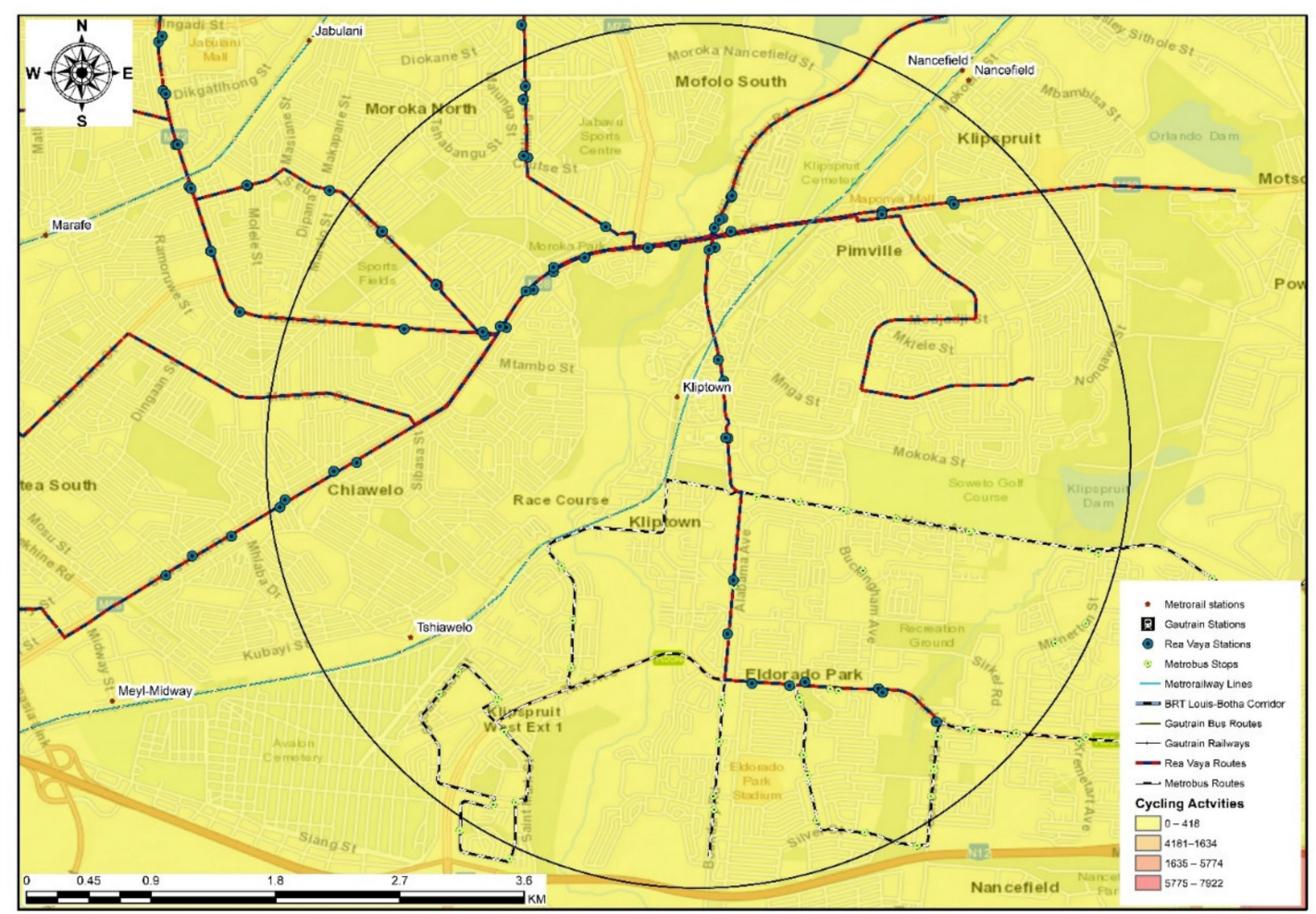

Figure 6. Soweto point of integration of urban public transport modes.

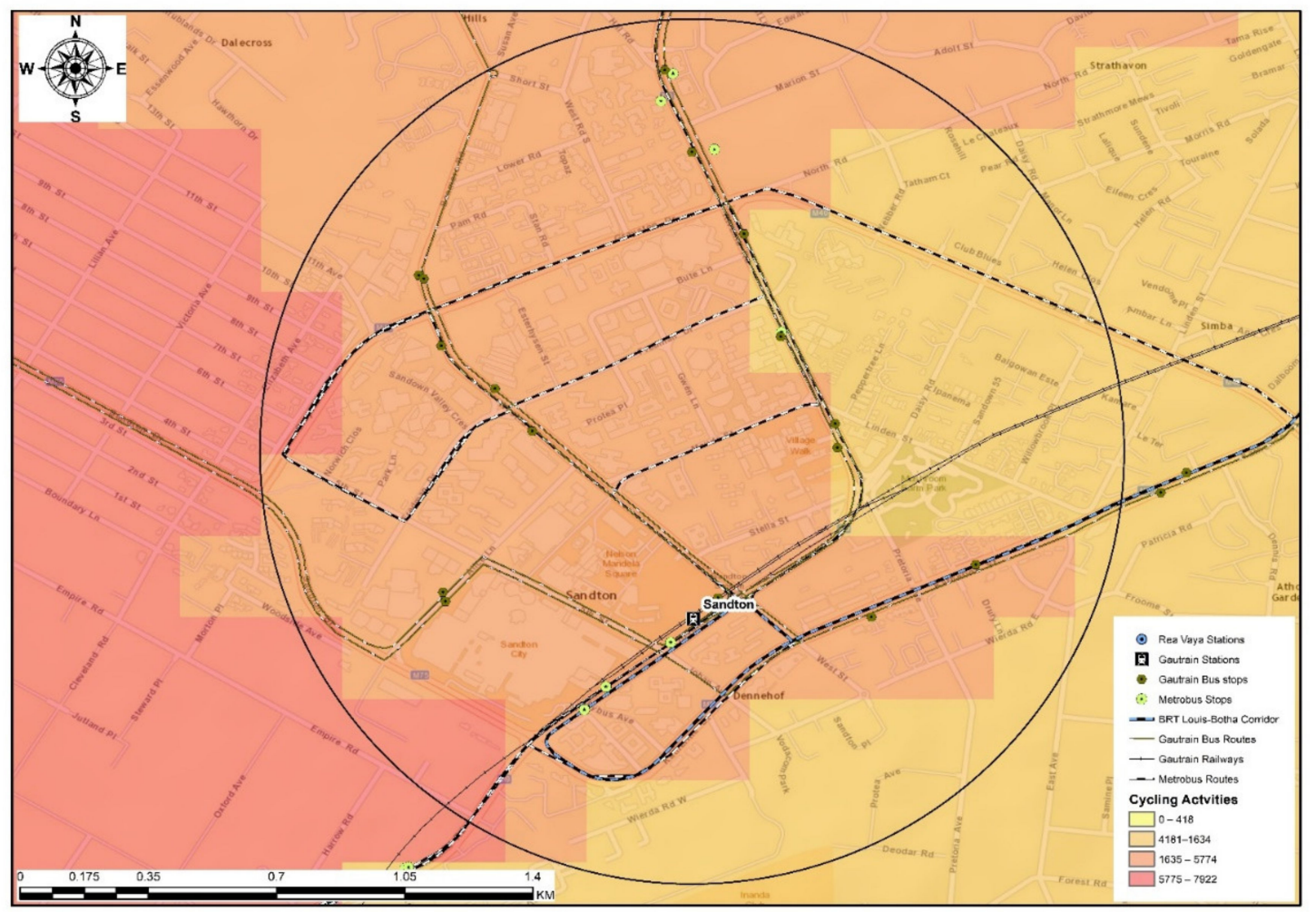

Figure 7. Sandton point of integration of urban public transport modes.

As illustrated in Figure 4, the Gautrain bus, Rea Vaya and Metrobus in the Inner City provide mobility for students, workers and patients from various locations (mostly from Park Station) to educational or health institutions. The existing urban public transport 
networks are spatially integrated. However, there is no sharing of infrastructure among these three modes of urban public transport, as they operate independently in this area. In terms of cycling, $15 \mathrm{~km}$ of dedicated lanes were implemented in the Inner City's streets as part of the university corridor from Doornfontein to Melville and with extensions to Westdene, Sophiatown, Langlaagte and Hillbrow. The Inner City's dedicated cycle lane connects students and staff members of both the universities of Johannesburg and Witwatersrand with surrounding residential and retail areas. These patterns have a direct influence on route choice preference, ease of movement and discernability within urban environments. The results reveal the Inner City as having cycling cold spots (with between 0-418 and 419-1634 cycling trips recorded in most areas).

\subsection{Analysis of Rosebank's Point of Integration}

Rosebank is a vibrant multi-cultural district, business node and tourist attraction, and it is a cosmopolitan commercial and residential suburb to the north of Johannesburg. Due to its compact size, visitors, residents and workers can walk the area, enjoying the outdoor atmosphere en route to their destinations. One of the latest and undoubtedly most exciting developments to take place in the area is that Rosebank was selected as a location for one of the five stations of the Gautrain Rapid Rail Transport System. Gautrain operates a train from Park Station to Rosebank every $15 \mathrm{~min}$. Metrobus operates from the corner of Jan Smuts Avenue and Empire Road in Braamfontein to the corner of Jan Smuts Avenue and Tyrwhitt Road in Rosebank. Figure 5 depicts the Rosebank point of integration for urban public transport modes and cycling activities.

Rosebank showed a higher concentration of cycling activities, and in support of this higher concentration of cycling activities, the interviews with city officials revealed that ZAR 70 million has been budgeted for the construction of the $20 \mathrm{~km}$ of cycle lanes linking Rosebank, Melrose Arch and Sandton. The routes would enable cyclists to ride from Rosebank to Sandton and from Rosebank to Melrose Arch through Melrose and Birdhaven. The route would pass the Wanderers Gym area on a loop from Rosebank to Saxonwold, then to Parkview, Zoo Lake, Greenside, Parkhurst and on to the Braamfontein Spruit mountain bike trail at Victory Park. The return to Rosebank would be along the Chester and Baker roads. The lanes are in line with the city's plan of embracing alternative modes of transport. The city of Johannesburg official further said, "a seamless transport system where people can switch from the Gautrain to the Metrobus or Rea Vaya, to taxis to cycling and walking, will significantly reduce the volume of private transport usage in the city".

\subsection{Analysis of Soweto's Point of Integration}

Soweto is one of the more densely populated areas in Johannesburg, already housing more than one third of the city's current population and having a growing middle class. In terms of public transport, Soweto is serviced by Rea Vaya, Metrobus and Metrorail, and is in relative proximity to the metropolitan core. Metrorail operates commuter trains between Soweto and the Inner City, with stations at Naledi, Merafe, Inhlazane, Ikwezi, Dube, Phefeni, Phomolong, Mzimhlophe, New Canada, Mlamlankunzi, Orlando, Nancefield, Kliptown, Tshiawelo and Midway. Figure 6 below depicts the potential areas of Rea Vaya, Metrobus and Metrorail network integration in Soweto.

The existing network and station infrastructure of Rea Vaya, Metrobus and Metrorail can open possibilities for mixed use transit-oriented development. However, there is currently no sharing of infrastructure, but the street networks are well connected internally, with high levels of walkability. The Metrobus within Soweto covers specific routes to accommodate people with disabilities, offering them service to and from work. There are six Metrobus buses that run along the following routes within Soweto: Soweto to Eldorado Park, Soweto to Johannesburg, Naturena to Johannesburg and Johannesburg to Sandton. Rea Vaya assists with the daily transport of workers from Soweto to Johannesburg and around the city. The Rea Vaya route in Soweto starts in Noordgesig and travels through Pimville, New Canada, Highgate, Auckland Park and Braamfontein to Parktown, plus 
the metro center and Rissik Street in the CBD. This route makes it possible for commuters to easily reach key public healthcare centers such as the Rahima Moosa, Helen Joseph and Charlotte Maxeke hospitals. Commuters using the route also gain easy access to educational institutions and workplaces. Rea Vaya feeder buses run from Protea Glen to Thokoza Park and from Eldorado Park to Lakeview. The intermodal hub at Park Station links the Metrorail, Metrobus and Gautrain services.

In terms of the concentration of cycling activities, Soweto showed a lower concentration of between 0 and 418 trips in most areas and 419 and 1634 in New Canada. Soweto has dedicated cycling routes, but due to safety, security and comfortability concerns, walking is a common non-motorized mode. The vast majority of internal trips are generally for social and retail purposes, and these mobilities consist of travel by car and on foot. Due to the short distances traveled to local social or retail opportunities, it can be said that the majority of these trips are made on foot. On-site observations indicated that there are numerous trips already made on foot despite inadequate pedestrian facilities.

\subsection{Analysis of Sandton's Point of Integration}

Sandton is a node that continues to be South Africa's premier office location, and it is anticipated to grow slowly and steadily. The node attracts daily commuters from all over Gauteng Province. People travel not only from the neighborhood adjacent to Sandton but from places as far away as Pretoria North, Roodepoort, Benoni, Vanderbijlpark and the East Rand. Sandton is currently serviced by Gautrain, Gaubus and Metrobus. It is a key destination in Phase 1C of Rea Vaya, which began construction in 2014. The Rea Vaya infrastructure also features $30.5 \mathrm{~km}$ of walking and cycling from Alexandra to Sandton, and it created interchanges that link with other modes of transport, such as the Metrobus and minibus taxis.

Figure 7 above depicts that there are areas where urban public transport networks are integrated in Sandton, although the system does not share infrastructure. In terms of cycling activities, Sandton is categorized as a hot spot, with between 418 and 1634, 1635 and 5774 and 5775 and 7922 trips in spaces such as Sandhurst, Sandown Strathavon and Sandton City, respectively. These cycling activities are integrated with the urban public transport infrastructure. However, in most public transit stations, there are no adequate cycling infrastructures, and public transport stations are not easily accessible for non-motorized transport. The challenge for Sandton is to facilitate continuous development growth in the context of additional travel demand and a limited transportation network that cannot be expanded easily. Transport infrastructure providing access to the node was initially designed to accommodate residential land uses and, at most, limited commercial land uses. The node is prone to traffic congestion during peak times. However, some of this congestion may be alleviated in the future because of the continued improvement in infrastructure along with the well-established transport system which is offered within the Sandton area, inclusive of the Gautrain Station, bus feeder routes and non-motorized transport.

\subsection{Cycling Activities and Station Concentration}

To ensure accuracy in spatial connectivity, it was crucial to analyze the cycling activities and station concentrations of urban public transport systems in Johannesburg. Stations of various modes were merged into one and analyzed together with the concentration of cycling activities. Using focal statistics analysis, a heat map was created to visualize the hot spots of urban public transport services in the city (see Figure 8). A clear distribution of hot and cold spots of transportation stations within the study area is evident. 


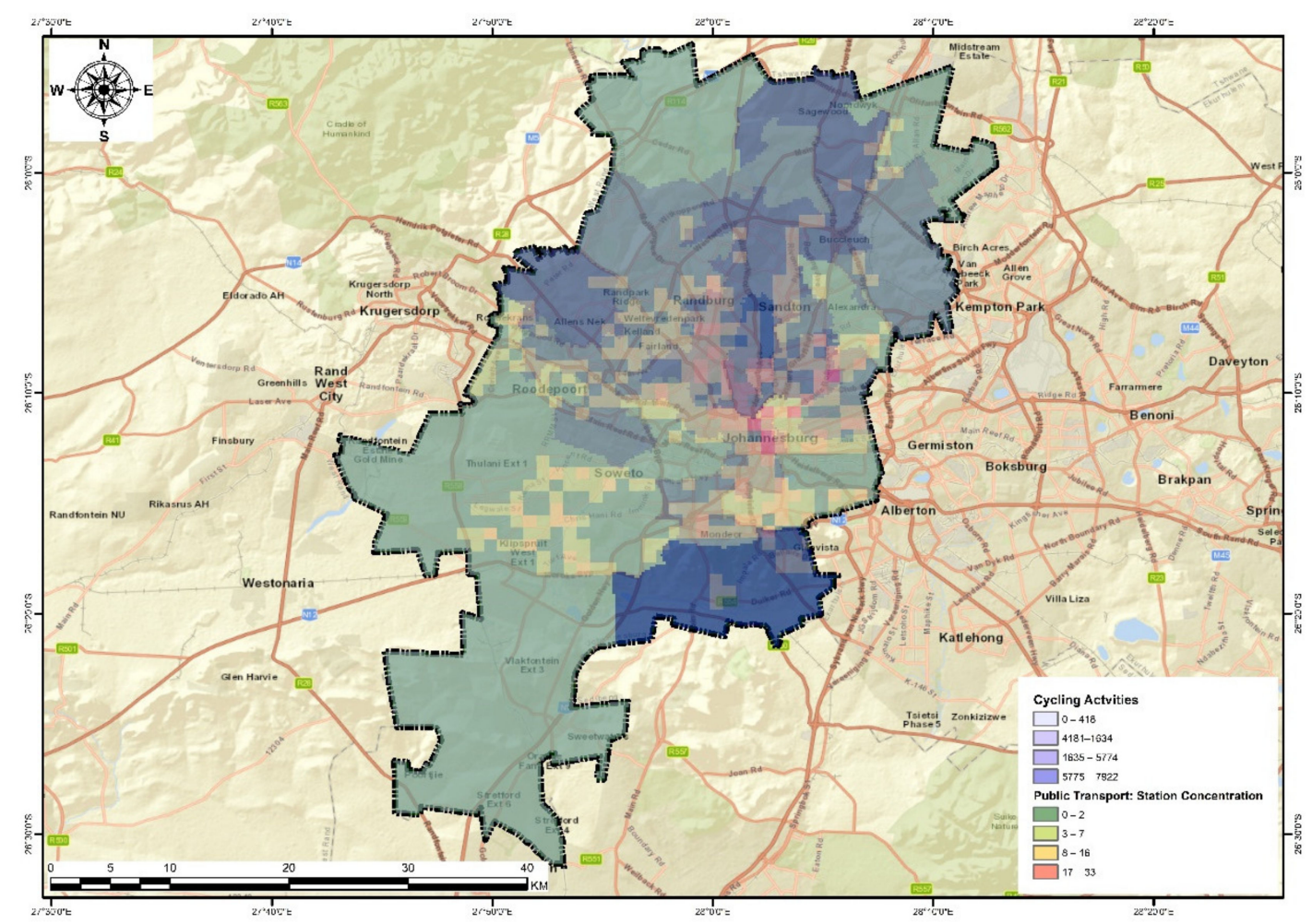

Figure 8. Integrated cycling activities and station concentration.

The integration analysis of non-motorized transport trends and urban public transportation concentrations revealed that the majority of the hot spots from the integrated map were located at the CBD, Randburg, Sandton and parts of Soweto. Noticeably, these locations are also near economic opportunities in the city, and hence they form key points of interest in the lives of commuters. An example is the Park Station node, which is located in the center of the CBD and acts as an entry point for most regional and local commuters. It also has close proximity to the Bree Street Taxi Rank and MTN Taxi Rank, being located only 10 min away. Therefore, Park Station has a high connectivity level.

\subsection{Johannesburg Park Station Intermodal Transport Node}

The results revealed that Johannesburg Park Station is the most integrated hub that is serviced by both non-motorized and urban public transport infrastructure. Public transport commuters at the station switch from one mode of transport to another smoothly at a short walking distance. Park Station also enriches service integration and reduces the time and distance penalties of rail-to-rail and rail-to-bus interchanges [13]. The crowd-sourced datasets derived from Strava demonstrated that Park Station was one of the highest cycling activity hot spots, ranging between 1635 and 5774 cycling trips for the year 2019. People in areas surrounding transit stops that lack cycling facilities at the station tend to travel less to access transit. Figure 9 below presents the spatial coverage of urban public transport modes and concentrations of cycling activities in Johannesburg Park Station. 


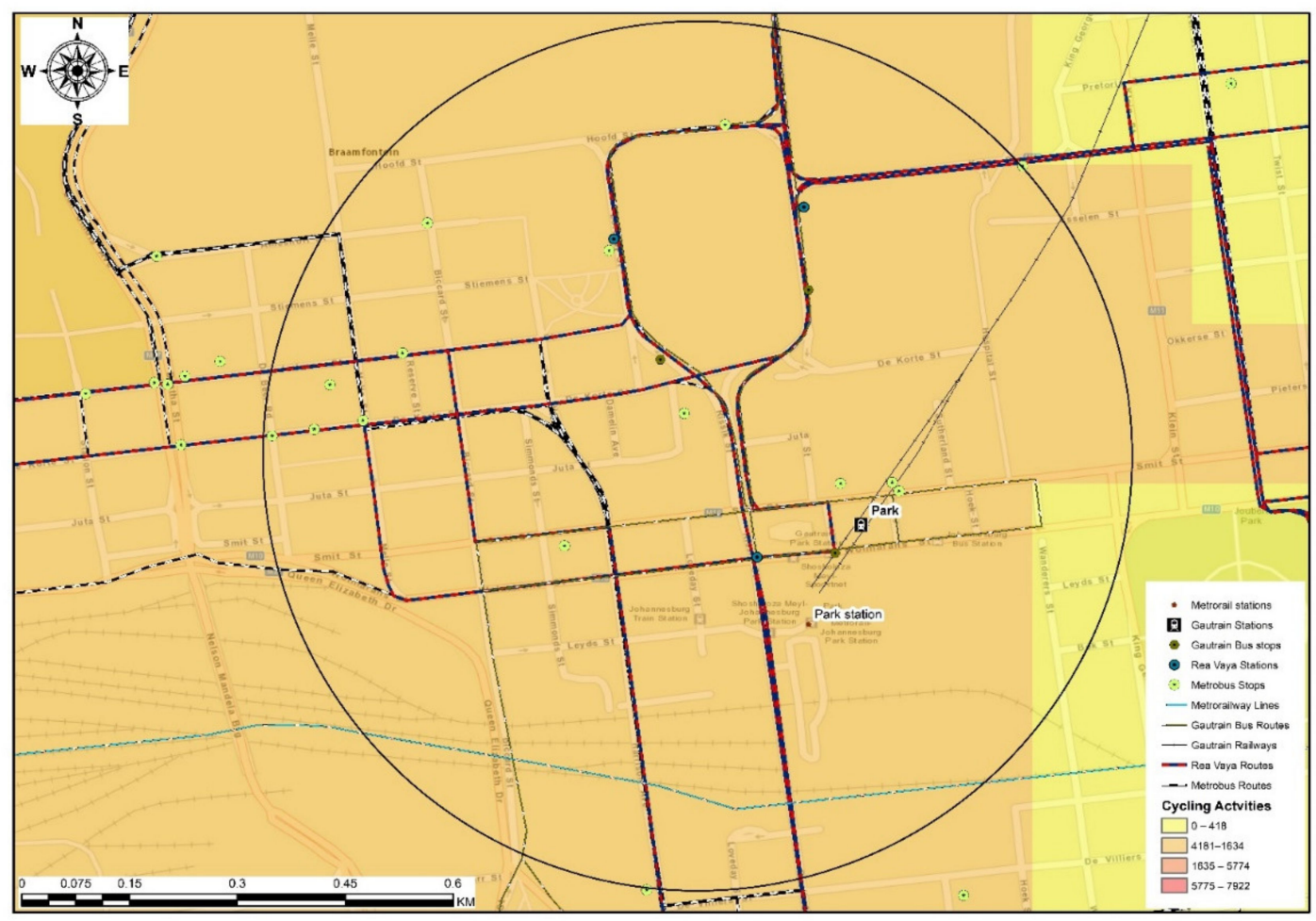

Figure 9. Spatial coverage of urban public transport modes and concentration of cycling activities in Johannesburg Park Station.

The station provides access to Johannesburg's Inner City and well-established highdensity precincts, which have undergone significant regeneration in recent years. Park Station is characterized by a mixture of high-intensity land uses. These range from the clustering of mostly commercial land use to the south of the station to a concentration of educational and government institutions, commercial, parking and other mixed land uses to the north. Due to the high intensity of land uses in the area, as well as the high volumes of people working at or visiting government, educational or commercial facilities, public parking is essential. Park Station is a prominent transport terminus in Johannesburg, Gauteng Province and Southern Africa; therefore, metro rail stations and platforms and taxi ranks are located within close proximity to the Park Station precinct. The Gautrain, bus routes as well as the Rea Vaya routes should also be noted as essential feeders and distributor routes in the area.

\section{Discussion}

The results show that Parkview, Hyde Park, Sandton, Randburg and Midrand are hot spots of cycling activities in Johannesburg. This pattern is also largely for recreational or commute-based cycling. The Inner City, Soweto, Lenasia and Orange Farm are cold spots of cycling activities. In the Inner City and Soweto, this is because of safety concerns, since motorists use cycling routes as parking bays and at times as an extension of driving lanes. The city has not invested in the implementation of cycling infrastructure for Region G and currently does not have any cycling plans for the region. Notably, Kibler Park and Sagewood in Midrand are not serviced by the existing urban public transport modes. This means that commuters who reside in these areas use cycling before they can access urban public transport modes. Therefore, these are potential areas to integrate and improve commuting and cycling infrastructure to enhance the use of multi-mobility. In terms of spatial integration with urban public transport systems, cycling activities are separated from the Gautrain, Rea Vaya, Metrorail and Metrobus. Commuting and cycling operations are spatially fragmented, with no sharing of infrastructure. 
In most public transport stations, there is no adequate cycling infrastructure, and these stations are not easily accessible for non-motorized transport. This affects commuters' ability to conveniently switch from either non-motorized mode to urban transport services. It would be of benefit for non-motorized transport with the three modes to partner toward promoting multi-mobility and the sharing of infrastructure. The results demonstrate that Johannesburg Park Station is the most integrated station serviced by both non-motorized and urban public transport systems, although the Inner City, in terms of the results, is a cycling cold spot. Commuters at the station switch smoothly from one mode of transport to another within a short walking distance. The station provides for an integrated and effective routing and circulation system which reduces the number of transfers required by commuters. It not only promotes the use of public as well as non-motorized transport but also encourages the integrated development of surrounding land uses. Each transport mode at the station supports the others by helping to redistribute commuters who overlap among them and by catering for commuters' requirements and demands. The station is surrounded by an existing ring road network which integrates the surrounding streets with interchanges and the south and north Johannesburg highways. The ring has three access points which help reduce traffic congestion because of the large commuter flows on the surrounding road network.

\section{Policy Implications and Lessons Learned}

The City of Johannesburg's Non-Motorized Transport Framework (2009) has long informed the promotion of commuter cycling and related investment in cycling infrastructure through policies such as Johannesburg's Integrated Transport Plan and the 2040 Growth and Development Strategy. The framework specifically promotes the integration of the cycling infrastructure with Gautrain, Rea Vaya, Metrorail and Metrobus stations to support an integrated approach to public transport. The Integrated Transport Plan calls for bike sharing as a means for increasing the availability of bicycles. Cities around the world have introduced bike sharing for a variety of reasons [14]. London, for instance, sought to reduce overcrowding on public transport, while Mexico City aimed to alleviate congestion on roadways [37,38]. Moreover, while the origin of a bike share program was introduced in Amsterdam in 1965, today, the scheme is financed through corporate sponsorship [16]. For Johannesburg, bike sharing is driven by a pro-poor, post-apartheid agenda of spatial transformation and sustainable development [17], and bike sharing programs have been observed as a way to connect commuters to public transport infrastructure. The city of Johannesburg's NMT framework identified ten potential cycling routes, two of which were realized in 2014 [28]. The first of these cycling routes began with the Orlando Pilot project, with a 5-km route starting at the Noordgesig Clinic, taking in the Orlando Stadium, Metrorail and Rea Vaya stations and 7 schools, and later, a 4-km lane between the universities of Johannesburg and the Witwatersrand [18].

Given the scenario of the city of Johannesburg, it was learned that improvement of urban public transport integration begins with focusing on the all-inclusive transportation chain instead of only one part of the journey. This includes facilitating spatial integration between diverse transport modalities to allow for a multiplicity of travel opportunities. The spatial integration of mobility modes leads to better quality of service delivery, interconnectivity of places of economic activity and advances in the quality of life. The results demonstrate that there are areas where the urban public transport networks are integrated, but great sections are disconnected. For example, at present, there is no partnership between Gautrain, Rea Vaya, Metrorail and Metrobus, as they are developed and serviced separately. A knowledge gap exists in the framework to integrate commuters with locations of economic activities. Thus, there is a need for the development of planning support frameworks which will guide the integration and growth of current and future public transport. 


\section{Conclusions}

This manuscript has assessed the extent of spatial integration between cycling activities and urban public transportation infrastructure using a developing city as a case study. The results reveal that the lack of integration between the NMT and motorized infrastructure is an impediment to the realization of a multi-modal system, as residents are unable to utilize cycling for the first and last mile of their commuting trips. In terms of spatial infrastructure, economic nodes in the city have the highest number of cycling activities. Identifying an urban public transportation catchment area becomes essential for developing cities such as Johannesburg, as this can be used as a tool for planning infrastructural upgrades and predicting potential public transport ridership while also assessing the impacts of investments in transit planning. It is suggested that future research should examine analytical features, including travel distance and durations of walking and cycling trips to access urban public transport services. The urban public transport service coverage should be measured by the amount of households and employment within transit catchment areas. Spatial boundaries of cycle-transit and pedestrian-transit catchment areas should be based on the identified distance thresholds and non-motorized accessibility to transport.

Author Contributions: Conceptualization, B.R.; methodology, B.R. and T.G.; software, B.R.; validation, B.R.; formal analysis, B.R. and T.G.; investigation, B.R. and T.G; resources, T.G.; data curation, T.G.; writing—original draft preparation, B.R.; writing—review and editing, T.G. and J.C.; visualization, B.R.; supervision, T.G. and J.C.; project administration, J.C. and T.G.; funding acquisition, T.G. All authors have read and agreed to the published version of the manuscript.

Funding: This work was funded by research funds of the individual coauthors to enable proofreading and editing, and the APC was funded by the University of Johannesburg Library publications support fund.

Institutional Review Board Statement: The study was conducted according to the guidelines of the Declaration of University of Johannesburg, and approved by the Faculty of Engineering and the Built Environment Higher Degrees Committee of University of Johannesburg, Johannesburg, South Africa (protocol code: FHDC7.30 (2020) and date of approval: 14 August 2021).

Informed Consent Statement: Informed consent was obtained from all subjects involved in the study.

Acknowledgments: The authors acknowledge all the participants whom their hard work and long hours contributed towards the fulfilment of this study.

Conflicts of Interest: The authors declare no conflict of interest.

\section{References}

1. McLeod, S.; Scheurer, J.; Curtis, C. Urban public transport: Planning principles and emerging practice. J. Plan. Lit. 2017, 32, 223-239. [CrossRef]

2. Arroub, A.; Zahi, B.; Sabir, E.; Sadik, M. (Eds.) A literature review on Smart Cities: Paradigms, opportunities and open problems. In Proceedings of the 2016 International Conference on Wireless Networks and Mobile Communications (WINCOM), Fez, Morocco, 26-29 October 2016.

3. Bibri, S.E.; Krogstie, J. Smart sustainable cities of the future: An extensive interdisciplinary literature review. Sustain. Cities Soc. 2017, 31, 183-212. [CrossRef]

4. Yigitcanlar, T.; Kamruzzaman, M. Smart cities and mobility: Does the smartness of Australian cities lead to sustainable commuting patterns? J. Urban Technol. 2019, 26, 21-46. [CrossRef]

5. Brakewood, C.; Rojas, F.; Robin, J.; Sion, J.; Jordan, S. Forecasting mobile ticketing adoption on commuter rail. J. Public Transp. 2014, 17, 1-19. [CrossRef]

6. Jain, S.; Aggarwal, P.; Kumar, P.; Singhal, S.; Sharma, P. Identifying public preferences using multi-criteria decision making for assessing the shift of urban commuters from private to public transport: A case study of Delhi. Transp. Res. Part F Traffic Psychol. Behav. 2014, 24, 60-70. [CrossRef]

7. Bellumori, M.; Uygur, M.; Knight, C.A. High-speed cycling intervention improves rate-dependent mobility in older adults. Med. Sci. Sports Exerc. 2017, 49, 106-114. [CrossRef] [PubMed]

8. Boulange, C.; Gunn, L.; Giles-Corti, B.; Mavoa, S.; Pettit, C.; Badland, H. Examining associations between urban design attributes and transport mode choice for walking, cycling, public transport and private motor vehicle trips. J. Transp. Health 2017, 6, 155-166. [CrossRef] 
9. Mbara, T.; Pisa, N. An analysis of impediments to deliver sustainable transport in cities of the developing countries: The case of Harare, Zimbabwe. WIT Trans. Built Environ. 2018, 182, 241-252.

10. Zuo, T.; Wei, H.; Chen, N. Promote transit via hardening first-and-last-mile accessibility: Learned from modeling commuters' transit use. Transp. Res. Part D: Transp. Environ. 2020, 86, 102446. [CrossRef]

11. Beukes, E.; Vanderschuren, M.; Zuidgeest, M. Context sensitive multimodal road planning: A case study in Cape Town, South Africa. J. Transp. Geogr. 2011, 19, 452-460. [CrossRef]

12. Mishra, S.; Welch, T.F.; Jha, M.K. Performance indicators for public transit connectivity in multi-modal transportation networks. Transp. Res. Part A: Policy Pract. 2012, 46, 1066-1085. [CrossRef]

13. Zhu, Z.; Zhang, A.; Zhang, Y. Connectivity of intercity passenger transportation in China: A multi-modal and network approach. J. Transp. Geogr. 2018, 71, 263-276. [CrossRef]

14. Arsenio, E.; Coelho, J. The role of sustainable urban mobility plans and ICT to improve public space for social inclusion. In Neighbourhood \& City: Between Digital and Analogue Perspectives; CyberParks: Lisbon, Portugal, 2017.

15. Khosa, M.M. "The travail of travelling": Urban transport in South Africa, 1930-1996. Transp. Rev. 1998, 18, 17-33. [CrossRef]

16. May, A.; Boehler-Baedeker, S.; Delgado, L.; Durlin, T.; Enache, M.; van der Pas, J.-W. Appropriate national policy frameworks for sustainable urban mobility plans. Eur. Transp. Res. Rev. 2017, 9, 7. [CrossRef]

17. Foltýnová, H.B.; Vejchodská, E.; Rybová, K.; Květoň, V. Sustainable urban mobility: One definition, different stakeholders' opinions. Transp. Res. Part D Transp. Environ. 2020, 87, 102465. [CrossRef]

18. Rahman, M.M.; D'Este, G.; Bunker, J.M. (Eds.) Non-motorized public transport: The past, the present, the future. In Proceedings of the 33rd Australasian Transport Research Forum 2010, Canberra, Australia, 29 September-1 October 2010; The Planning and Transport Research Centre (PaTReC): Crowley, Australia, 2010.

19. Wang, J.; Samsura, D.A.A.; van der Krabben, E. Institutional barriers to financing transit-oriented development in China: Analyzing informal land value capture strategies. Transp. Policy 2019, 82, 1-10. [CrossRef]

20. Ranchordás, S. Smart Mobility, Transport Poverty and the Legal Framework of Inclusive Mobility. In Smart Urban Mobility; Finck, M., Lamping, M., Moscon, V., Richter, H., Eds.; Springer: Berlin/Heidelberg, Germany, 2020; pp. 61-80.

21. Moyo, T.; Kibangou, A.Y.; Musakwa, W. Societal context-dependent multi-modal transportation network augmentation in Johannesburg, South Africa. PLoS ONE 2021, 16, e0249014. [CrossRef]

22. Adewumi, E.; Allopi, D. Rea Vaya: South Africa's first bus rapid transit system. S. Afr. J. Sci. 2013, 109, 1-3. [CrossRef]

23. Arnold, K.; Le Roux, A.; Hattingh, M. Impact of Gautrain stations on property prices and sales activity in the City of Johannesburg between 2006 and 2015. S. Afr. J. Geomat. 2017, 6, 184-195. [CrossRef]

24. Ndwandwe, B.; Gumbo, T. Progressive or regressive: Efficacy of innovative urban public transport systems on urban mobility in the City of Tshwane. In Proceedings of the 2018 37th Southern African Transport Conference, “Towards a Desired Transport Future: Safe, Sufficient and Affordable", Pretoria, South Africa, 9-12 July 2018.

25. Mbatha, S.; Gumbo, T. (Eds.) Establishing the State of Spatial Integratedness of Innovative Public Transport Systems in Gauteng, South Africa. In Proceedings of the REAL CORP 2019: 24th International Conference on Urban Planning and Regional Development in the Information Society GeoMultimedia 2019, Karlsruhe, Germany, 2-4 April 2019.

26. Scorcia, H.; Munoz-Raskin, R. Why South African cities are different? Comparing Johannesburg's Rea Vaya bus rapid transit system with its Latin American siblings. Case Stud. Transp. Policy 2019, 7, 395-403. [CrossRef]

27. Simpson, Z.; McKay, T.; Patel, N.; Sithole, A.; Chipp, K.; Mambo, J. Past and Present Travel Patterns in the Gauteng City-Region; Gauteng City Region Observatory: Johannesburg, South Africa, 2012.

28. Musakwa, W.; Gumbo, T. Impact of urban policy on public transportation in gauteng, South Africa: Smart or dumb city systems is the question. In Carbon Footprint and the Industrial Life Cycle; Álvarez Fernández, R., Martínez, R., Zubelzu, S., Eds.; Springer: Cham, Switzerland, 2017; pp. 339-356.

29. Moyo, T.; Musakwa, W.; Mokoena, B.T. An analysis to investigate spatial cognitive factors which influence cycling patterns in Johannesburg. Int. Arch. Photogramm. Remote Sens. Spat. Inf. Sci. 2018, XLII-4/W11, 43-49. [CrossRef]

30. Musakwa, W.; Selala, K.M. Mapping cycling patterns and trends using Strava Metro data in the city of Johannesburg, South Africa. Data Brief 2016, 9, 898-905. [CrossRef]

31. Risimati, B.; Gumbo, T. (Eds.) Mapping the Spatial Integration of Motorized and Non-Motorized Transport Infrastructures: A Case Study of the City of Johannesburg. In Proceedings of the REAL CORP 2019: 24th International Conference on Urban Planning and Regional Development in the Information Society GeoMultimedia 2019, Karlsruhe, Germany, 2-4 April 2019.

32. Moyo, T.; Musakwa, W.; Kibangou, A.; Gumbo, T.; Ingwani, E. (Eds.) The potential of using volunteered locational data in planning for smart multi-mobility systems. In Proceedings of the REAL CORP 2019: 24th International Conference on Urban Planning and Regional Development in the Information Society GeoMultimedia 2019, Karlsruhe, Germany, 2-4 April 2019.

33. Sun, Y.; Du, Y.; Wang, Y.; Zhuang, L. Examining associations of environmental characteristics with recreational cycling behaviour by street-level Strava data. Int. J. Environ. Res. Public Health 2017, 14, 644. [CrossRef] [PubMed]

34. Lee, K.; Sener, I.N. Understanding potential exposure of bicyclists on roadways to traffic-related air pollution: Findings from El Paso, Texas, using Strava metro data. Int. J. Environ. Res. Public Health 2019, 16, 371. [CrossRef] [PubMed]

35. McArthur, D.P.; Hong, J. Visualizing where commuting cyclists travel using crowdsourced data. J. Transp. Geogr. 2019, 74, $233-241$. [CrossRef] 
36. Selala, M.; Musakwa, W. The potential of strava data to contribute in non-motorized transport (NMT) planning in Johannesburg. Int. Arch. Photogramm. Remote Sens. Spatial Inf. Sci. 2016, XLI-B2, 587-594. [CrossRef]

37. Metz, D. Peak car in the big city: Reducing London's transport greenhouse gas emissions. Case Stud. Transp. Policy 2015, 3, 367-371. [CrossRef]

38. Chatziioannou, I.; Alvarez-Icaza, L.; Bakogiannis, E. A structural analysis method for the promotion of Mexico City's integral plan of mobility. Cogent Eng. 2020, 7, 1759395. [CrossRef] 